\title{
HEDGES USED BY INDONESIAN ELT STUDENTS IN WRITTEN AND SPOKEN DISCOURSES
}

\author{
Risda Asfina' \\ A. Effendi Kadarisman ${ }^{2}$ \\ Utari Praba Astuti ${ }^{3}$ \\ Universitas Negeri Malang, Indonesia \\ risda.asfina@gmail.com'; effendi.kadarisman@gmail.com²; utari_pastuti@yahoo.com³
}

First received: 30 August 2017

Final proof received: 31 January 2018

\begin{abstract}
Hedging expression is considered an important interactional metadiscourse device which shows the writer's/speaker's degree of confidence in the truth of a proposition and his/her attitude to the readers or listeners in academic discourse. Although considerable research on hedges has been undertaken, there have been virtually no studies on hedges in spoken discourse in educational contexts. To fill this gap, this study aims at describing and comparing the use of hedges by Indonesian ELT students in written and spoken discourses. This study is descriptive qualitative in nature. The research subjects were 20 ELT graduate students registered in 2015 at a state university in East Java, Indonesia. The sources of data were the students' thesis proposals and thesis proposal presentations, particularly the 'background of the study' section. As such, the study used a corpus-based approach which utilized concordance software, i.e. AntConc (3.4.4), to examine the frequency of hedges based on types. The use of hedges was categorized on the basis of hedges taxonomy adapted from Salager-Meyer (1994) and Hyland (2005). The findings of this study revealed that (i) in terms of types and frequency, the patterns of the use of hedges types (from the most to the least frequently used) by ELT students in both corpora were almost similar: WD: S-Ap-Em-Ex-Ch, and SD: S-Ap-Ex-Em-Ch (see Table 2 for legends); (ii) ELT students employed more hedges in written discourse than in spoken discourse; and (iii) approximately $65 \%$ of hedges variants provided in the taxonomy were employed by ELT students in written and spoken discourses. On the basis of the results of the study, the discourse mode (written or spoken) can be a factor that affects the use of hedges in academic discourse.
\end{abstract}

Keywords: hedges; written discourse; spoken discourse; ELT students

Hedging expression is a useful metadiscourse device used to represent writers'/speaker' stance. According to Hyland (2005), it is categorized into interactional metadiscourse. Unlike interactive metadiscourse, interactional metadiscourse is more personal, direct, and evidently related to interpersonality. In other words, hedging expression shows the way the writer or speaker makes his/her explicit views on a proposition and conduct interaction to involve the readers or listeners in the discourse. Hedging expression is used to modify the writer's/speaker's claims to generate dialogical academic discourse (Hyland, 2000; Seskauskiene, 2008). More specifically, Khajavy, Asadpour and Yousefi (2012) reveal that hedges show the reluctance of the writer or speaker to present propositional information categorically. In addition, Hyland as cited in Algi (2012) defines hedges as words that sign propositions based on possible reasoning and allow the writer or speaker to let the readers or listeners express their interpretations. Further, types of hedges and their description are presented in Table 1 .

Hedging expression is considered an important discourse marker in academic discourse. Its necessity in academic discourse lies in its contribution to an appropriate rhetorical and interactive tenor, delivering epistemic and affective meanings (Hyland, 1998). The way the writers or speakers evaluate the certainty of their assertions is central to the meaning of academic discourse (Hyland, 2000). Specifically in ELT context, according to Seskauskiene (2008), it is necessary that students acquire the 'right kind of language' to express their ideas in the selected field (the propositional content) and to bear pragmatic, cognitive and rhetorical values which contribute to the overall meaning of the discourse. Briefly, hedging expression is essential to carry the writer's/speaker's degree of confidence in the truth of a proposition in academic discourse, either written or spoken, and his/her attitude to the readers or listeners. Importantly, it shows the writer's/speaker's readiness to receive alternative views on the propositions (Heng \& Tan, 2010). It is supported by Ruzaite (2004) who argues that vague language is a frequent option in academic discussions since it can have positive purposes in communication.

There have been several researchers conducting studies on hedges in written discourse. Some of them are the studies by Saiful (2005), Takimoto (2015), Serholt 
(2012), and Getkham (2016). Saiful (2005) found out that when writers hedged a maxim it could bear three possible implications: they did not want to get involved in any further discussion; they expressed a message only for politeness; or they were cautious in expressing a claim of probability. Takimoto (2015) came up with the finding that hedging expression is more commonly used in research articles in the humanities and social sciences since they are basically more interpretative and less abstract-a style that requires more hedges and opts for subjectivity. Serholt (2012) and Getkham (2016) found out that hedges appeared more frequently in the 'discussion' and 'introduction' sections, consecutively, in academic writing.

Table 1. Types of Hedges and Their Description (Hyland, 2005; Kaltenbock, Mihatsch, \& Schneider, 2010; Riekkinen, 2009; Ruzaite, 2004; Salager-Meyer, 1994; Sundquist, 2013)

\begin{tabular}{|c|c|c|}
\hline No. & Type & Description \\
\hline 1. & Shields & $\begin{array}{l}\text { To implicate a level of uncertainty by providing plausible reasoning. } \\
\text { e.g. all modal verbs expressing possibility, seem, probably, likely, speculate }\end{array}$ \\
\hline 2. & $\begin{array}{l}\text { Approximators of quantity, } \\
\text { degree, frequency and time which } \\
\text { express heed and coyness }\end{array}$ & $\begin{array}{l}\text { To give range on quantity, degree, frequency and time when more precision } \\
\text { is unattainable or to make utterances less assertive by decreasing their } \\
\text { exactness. } \\
\text { e.g. approximately, somewhat, quite, often, occasionally }\end{array}$ \\
\hline 3. & $\begin{array}{l}\text { Expressions which express the } \\
\text { authors' personal doubt and direct } \\
\text { involvement }\end{array}$ & $\begin{array}{l}\text { To state personal evaluation that renders the utterance less threatening. } \\
\text { e.g. I believe, to our knowledge, it is our view that... }\end{array}$ \\
\hline 4. & Emotionally-charged intensifiers & $\begin{array}{l}\text { To project the writer's/speaker's reactions. } \\
\text { e.g. extremely difficult, dishearteningly weak, of particular importance, } \\
\text { unexpectedly, surprisingly }\end{array}$ \\
\hline 5 . & $\begin{array}{l}\text { Compound hedges which } \\
\text { comprise "strings of hedges" }\end{array}$ & $\begin{array}{l}\text { To juxtapose several hedges. } \\
\text { e.g. double hedges (it could be suggested that...); triple hedges (it would } \\
\text { seem likely that...); quadruple hedges (it would seem somewhat unlikely } \\
\text { that...) }\end{array}$ \\
\hline
\end{tabular}

Other studies examined the use of hedges from the 'discussion' section of academic writing, e.g. the studies by Agustina (2014) and Resmayani (2016). They revealed that five types of hedging expressions were used by undergraduate, master's and doctoral students: (a) shields; (b) approximators of degree, quantity, frequency, and time; (c) author's personal doubt and direct involvement; (d) emotionallycharged intensifiers; and (e) compound hedges. There was no significant difference in the use of hedges both between males and females and between ELT and ELL students in terms of frequency.

Nevertheless, only a few studies on hedges have been conducted in spoken discourse, e.g. the studies by Rashady (2012); Granqvist (2013); and Pellby (2013). Rashady (2012) analyzed three presidential debates to investigate how hedging devices serve a function as a discourse politics strategy. He discovered that hedging devices serve different functions depending on the intention or purpose of the speaker. In addition, the frequent use of certain hedging devices appears to significantly promote the effectiveness of a speaker's argument. Granqvist (2013) investigated the overall frequency of hedges in a TV show and examined whether this device displayed any gender differences. The results of her study showed that the female characters used hedges slightly more frequently. In line with Granqvist, Pellby (2013), in her study which aimed to examine the use of hedges among men and women in an American district council meeting, also revealed that women hedged more than men in the meeting. These occurrences mostly involved the epistemic modal function and shields.

Moreover, some scholars have exposed several distinctive points between written and spoken language: paralinguistic signals, preciseness, organization, deviations from default/unmarked orders, lexical diversity, and frequency of repetition (Moses in Chafe \& Tannen, 1987; and Bartsch in Ghasemi \& Jahromi, 2014). One of the distinctive points, preciseness, deals with the writer's or speaker's commitments on the propositions, including the use of hedges. Thus, this study aims to investigate and compare the use of hedges by Indonesian ELT students in written and spoken discourses. The former refers to their thesis proposals, and the latter to their thesis proposal presentations.

As revealed by previous studies, hedging expressions appear frequently in the 'discussion' and 'introduction' sections of academic writing. Since there have been no previous studies focusing on the 'introduction' section, this study therefore deals specifically with this part, particularly with the 'background of the study' section.

Moreover, according to Pedoman Penulisan Karya Ilmiah (2010) at the university under examination, in the background of the study in every research design, a researcher needs to build a strong foundation of why s/he wants to conduct the study. 
In quantitative research, it contains the researcher's viewpoints about the discrepancy between expectation and reality, either theoretical or practical discrepancy. In qualitative research, it comprises what the study is aimed at and what/who affects the aim of the study. In library research, it includes a general elaboration or description obtained from books, articles, newspapers, and magazines related to the issue being researched to support/oppose the researcher's ideas. In research and development research, it covers the context of the study and the development of a project for the sake of solving certain problems. In classroom action research, it contains the elaboration of certain problems, usually derived from educators'/researchers' observation and reflection toward the learning quality. Briefly, there can be a wide variety of research designs used in thesis proposals as determined by different types of research. At this point, it is worth noting that the present study used ELT students' thesis proposals as sources of data regardless of their research designs.

Taking all the aforementioned studies and the discussion into account, a study on the use of hedges, particularly studies in spoken discourse in educational contexts, needs to be conducted in order to touch on this issue more comprehensively. For this reason, this study is intended to fill the gap by taking a close look at the use of hedges not only in written discourse but also in spoken discourse in English Language Teaching (ELT) context.

The general research problem in this study is broken down and formulated into three specific questions: (i) how do ELT students employ hedges in written and spoken discourses in terms of types and frequency? (ii) in which discourse (written or spoken) do ELT students employ more hedges? and (iii) what is the distribution of hedges variants used by ELT students in written and spoken discourses?

\section{METHOD}

This study employed a descriptive qualitative design that used a corpus-based approach. The research subjects were 20 ELT graduate students registered in 2015 at a state university in East Java, Indonesia who had a thesis proposal seminar in their fourth semester, 2017. The selection of the subjects was adjusted to the catalog of graduate program in English language teaching at this university. The sources of data were the students' thesis proposals (written) and thesis proposal presentations (spoken), particularly the 'background of the study' section.

This study utilized concordance software, i.e. AntConc (3.4.4), particularly the features of Concordance providing KWIC and File View, developed by Anthony (2014) to examine the frequency of hedges based on types. In identifying whether the words in the corpora were categorized into hedges or not, English dictionaries software was used, i.e. Cambridge Dictionary (2008), Longman Dictionary (2006) and Oxford Dictionary (2008). Additionally, an audio recorder was employed to record the students' thesis proposal presentations and AntFileConverter (1.2.0) tool, developed by Anthony (2015), was used to convert (.docx) format of the thesis proposals into (.txt) files. Furthermore, the use of hedges was investigated based on hedges taxonomy adapted from Salager-Meyer (1994) and Hyland (2005) (see Appendix 1).

\section{FINDINGS AND DISCUSSION}

The size of the entire corpora analyzed in this study was 77,532 words with 61,614 words in thesis proposal corpus and 15,918 words in thesis proposal presentation corpus.

\section{Occurrences of Hedges in Written and Spoken} Discourses in Terms of Types and Frequency

This section presents an answer to the first research question. There were 902 hedges in thesis proposal corpus and 219 hedges in thesis proposal presentation corpus. In terms of types and frequency, the patterns of using hedges in both corpora were almost similar. The results of the calculation are presented in Table 2.

Table 2. Frequency of Hedges

\begin{tabular}{|c|c|c|c|c|c|c|c|c|}
\hline \multirow{2}{*}{ No. } & \multirow{2}{*}{ Number of Subjects } & \multirow{2}{*}{ Corpus } & \multicolumn{5}{|c|}{ Hedges Frequency } & \multirow{2}{*}{ Total } \\
\hline & & & $\mathrm{S}$ & $\mathrm{Ap}$ & Ex & Em & $\mathrm{Ch}$ & \\
\hline 1. & & Thesis Proposal & 661 & 238 & 1 & 2 & 0 & 902 \\
\hline 2. & 20 & Thesis Proposal Presentation & 157 & 58 & 3 & 1 & 0 & 219 \\
\hline
\end{tabular}

Where:
$\mathrm{S} \quad=$ Shields
$\mathrm{Ap} \quad=$ Approximators of quantity, degree, frequency and time which express heed and coyness
$\mathrm{Ex} \quad=$ Expressions which convey the authors' personal doubt and direct involvement
$\mathrm{Em} \quad=$ Emotionally-charged intensifiers (comment words used to project the authors 'reactions)
$\mathrm{Ch}=$ Compound hedges which comprise "strings of hedges"

The highest frequency was Shields (S) type $(\mathrm{TP}=661 / 73.28 \%$ and $\mathrm{TPP}=157 / 71.69 \%)$. It is in line with Pellby's (2013) study. She examined the use of hedges in spoken discourse in a political 
context and found that Shields, particularly the modal function, appeared to be the most frequently used in the same way. Despite the divergent contexts (education and politics), this congruent result is plausibly because both studies are included in the humanities and social sciences which are basically more interpretative and less abstract to promote the effectiveness of a writer's/speaker's arguments (Takimoto, 2015; Rashady, 2012).

The second highest frequency was Approximators of quantity, degree, frequency, and time (Ap) type: in TP $=238(26.39 \%)$ and in TPP $=58(26.48 \%)$. It is reasonable that this type of hedges was often employed by ELT students in both types of discourse if we refer to the idea of Wang (2010) that the things in the world are infinite and most of them are vague themselves, e.g. tall, red, big, round. They do not have clear boundaries; on the other hand, the vocabulary used to denote them is relatively finite. Therefore, when people are not really sure of a certain quantity, degree, frequency and time, they choose fuzzy language.

In addition, there were no Compound hedges (Ch) found in both corpora. It is different from the result of the study in written discourse conducted by Seskauskiene (2008), who discovered that the least frequent hedges found in her study were either longer words or phrases. In addition, Agustina (2014) also discovered that all types of hedging expressions including Compound hedges $(\mathrm{Ch})$ were used by her research subjects in academic discourse, particularly in written discourse. This difference is presumably due to the distinct sections of the academic discourse employed as the source of data; she focused on the discussion section, while this study focused on the introduction section, specifically the 'background of the study' section.

However, different patterns were found in the third and fourth positions of hedges types used. In the proposal corpus, the Emotionally-charged intensifiers (Em) type was used more frequently than the Expressions which convey personal doubt and direct involvement (Ex) type: $\mathrm{Em}=2(0.22 \%)$ and $\operatorname{Ex}=1(0.11 \%)$. On the other hand, in thesis proposal presentation corpus, Ex was used more often than Em: $\mathrm{Ex}=3(1.37 \%)$ vs. $\mathrm{Em}=1(0.46 \%)$. Based on the functions of those types of hedges in written discourse, according to Riekkinen (2009) and Salager-Meyer (1994), the students project their reactions more than state their personal evaluation that renders the utterance less threatening, while in spoken discourse, they state their personal evaluation more than project their reactions. It is probably because the spoken mode is more direct; the students presented their thesis proposal directly in front of the advisors and the audience. Therefore, they frequently expressed their personal view and direct involvement by saying, for instance, I believe. On the contrary, the written mode is less direct; the students did not write their thesis proposal under the scrutinizing eyes of any reader. As a result, they felt more free to use Emotionally-charged intensifiers to project their reactions, e.g. by saying surprisingly, essentially. Examples of sentences containing hedges in a student's thesis proposal and another's thesis proposal presentation are shown below.

Excerpt 1:

"The process of reviewing from the related literature can be the source of opportunities for the students to commit plagiarism." (TP_4)

Excerpt 2:

"...although most of the teachers, yeah as the participants, had highly level of understanding about TBLT, they still had some fear to adopt TBLT in the classroom...." (TPP_10)

When a writer is composing written discourse or a speaker is delivering spoken discourse, s/he may employ fuzzy language, e.g. hedges (Wang, 2010). Specifically, s/he uses certain types of this metadiscourse device to formulate the messages. In this way, the writer/speaker can achieve the desired communication intentions. Moreover, Rashady (2012) reveals that hedges types serve different functions depending on the intention or purpose of the writer/speaker, meaning that the pattern (in terms of frequency) of using hedges is associated with the types which meet the writer's/speaker's intention or purpose.

\section{Comparison between Hedges in Written and} Spoken Discourses in terms of Frequency

This section provides an answer to the second research question. The comparative analysis between the hedges in students' thesis proposals and thesis proposal presentations was eventually converted into the normalized frequency to ensure that the data were comparable. The calculation of the normalized frequency of hedges was done based on the formula suggested by Resmayani (2016). The results of the calculation were in per thousand words (ptw). They are presented in Table 3.

Table 3. Normalized Frequency of Hedges

\begin{tabular}{|c|c|c|c|c|c|c|c|c|}
\hline \multirow{2}{*}{ No. } & \multirow{2}{*}{ Number of Subjects } & \multirow{2}{*}{ Corpus } & \multicolumn{5}{|c|}{ Normalized Frequency } & \multirow{2}{*}{ Total } \\
\hline & & & $\mathrm{S}$ & $\mathrm{Ap}$ & Ex & Em & $\mathrm{Ch}$ & \\
\hline 1. & & Thesis Proposal & 10.73 & 3.86 & 0.02 & 0.03 & 0 & $14.64 \mathrm{ptw}$ \\
\hline 2. & 20 & $\begin{array}{l}\text { Thesis Proposal } \\
\text { Presentation }\end{array}$ & 9.86 & 3.64 & 0.19 & 0.06 & 0 & 13.76 ptw \\
\hline
\end{tabular}


ELT students employed more hedges in thesis proposals than in thesis proposal presentations although the difference was not substantial. The more frequent use of hedges in written discourse in this study seems to be caused by several implications, as discovered by Saiful (2005) and Sundquist (2013): they do not want to get involved in further discussion or they want to diminish the argument with the readers; they express a message for politeness; or they are cautious in expressing a claim of probability.

Moreover, written mode requires the writers to produce less cognitive effort than the speakers do in spoken discourse (Daniel, Przytula, and Denis, 2009). Consequently, the written mode leads to less dynamic discourse. The writers take more distance from what they say and describe the general surroundings. In addition, the written mode is more formal than the spoken mode, thus requiring students to produce more polite and mitigating language. This is supported by Koch and Oesterreicher in Areta (2015), who claim that the distinction between written and spoken modes lies in the degrees of formality involved in the discourse that leads to the so-called pole of 'communicative distance' and pole of 'communicative proximity'. Therefore, the students tend to be less certain in showing their position in written discourse than in spoken discourse. They have less sense of confidence to demonstrate and boost their stance in written discourse. The clear picture comparing the use of hedges in thesis proposals and thesis proposal presentations can be seen in Figure 1.

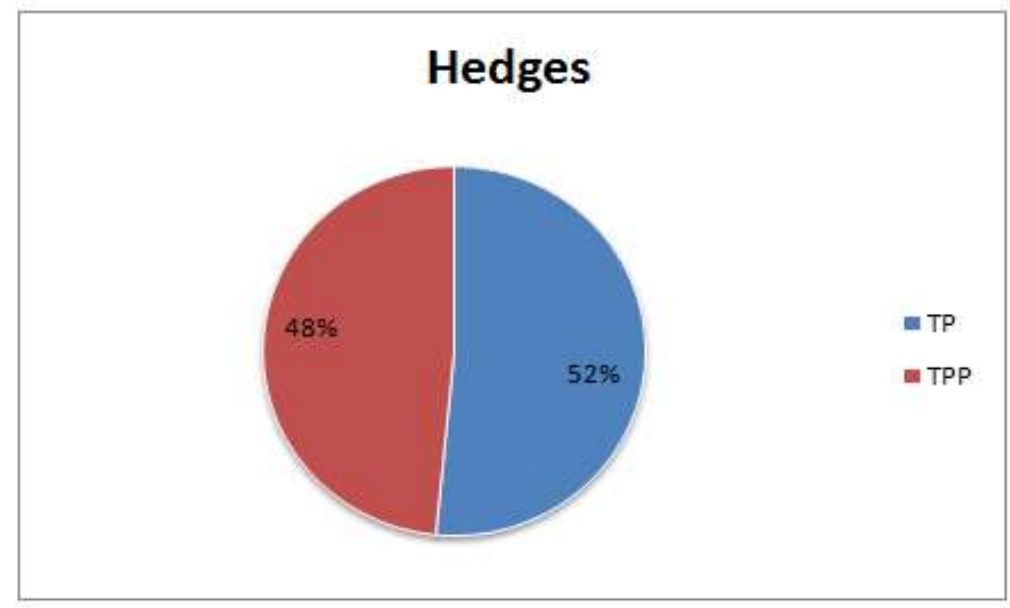

Figure 1. Hedges in thesis proposals and thesis proposal presentations

\section{Distribution of Hedges Variants in Written and Spoken Discourse}

This section gives an answer to the third research question. This study found that from the total of 72 hedges variants $(S=32, A p=24, E x=6, E m=5$, $\mathrm{Ch}=5)$, there were 47 hedges variants which occurred in the corpora. It means that $65.28 \%$ of hedges variants provided in the taxonomy were employed by ELT students in the 'background of the study' section of their thesis proposals and thesis proposal presentations. This phenomenon is closely related to the students' lexical richness since lexical richness involves several measurements, one of which is lexical variation (Laufer \& Nation, 1995). It implies that the higher lexical richness the students have, the more hedges variants they employ.

Moreover, in order to dig up the distribution of occurrences of hedges variants in each type more deeply, we counted the number of hedges variants used in the corpora for each type. Further, we calculated the percentage of their occurrences; we counted the number of variants used in each type, divided by total of variants in that type, and multiplied by $100 \%$. The results of the calculation are shown in Table 4.

Table 4. Occurrences of Hedges Variants Based on Types

\begin{tabular}{ccrrrc}
\hline \multirow{2}{*}{ No. } & Type & \multicolumn{3}{c}{ Variants } \\
\cline { 3 - 6 } & S & 25 & $78.13 \%$ & 15 & TPP \\
\hline 1. & Ap & 17 & $70.83 \%$ & 14 & $58.88 \%$ \\
2. & Ex & 1 & $16.67 \%$ & 1 & $16.67 \%$ \\
3. & Em & 2 & $40 \%$ & 1 & $20 \%$ \\
4. & Ch & 0 & $0 \%$ & 0 & $0 \%$ \\
5. & & &
\end{tabular}

ELT students employed hedges variants in both corpora differently in terms of quantity almost in all types of hedges. In three out of five types of hedges (i.e. Shields (S), Approximators of quantity, degree, frequency and time (Ap), and Emotionallycharged intensifiers $(\mathrm{Em})$ ), the students employed 
more hedges variants in thesis proposals than in thesis proposal presentations. What is more, as regards the Emotionally-charged intensifiers (Em) type, the students used hedges variants in thesis proposals twice as much as in thesis proposal presentations. Nevertheless, in the other two types of hedges (i.e. expressions which convey personal doubt and direct involvement (Ex) and Compound hedges $(\mathrm{Ch})$ ), the students employed hedges variants in both corpora similarly in terms of quantity. The clear depiction on the comparison between occurrences of hedges variants based on types can be seen in Figure 2 .

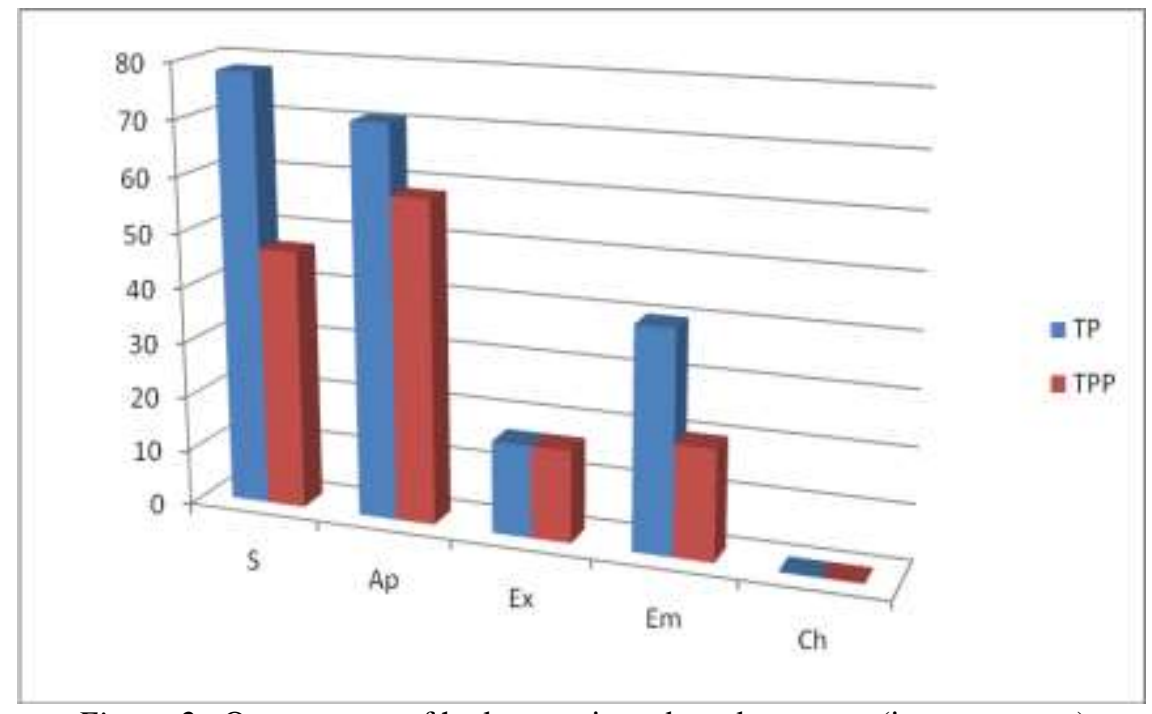

Figure 2. Occurrences of hedges variants based on types (in percentage)

Almost in all types of hedges, ELT students employed more hedges variants in thesis proposals than in thesis proposal presentations. With two types of hedges (i.e. Ex and Ch), they used the variants equally often in both corpora. In addition, no types of hedges showed more use of the variants in thesis proposal presentations than in thesis proposals. This phenomenon is supported by the idea of Moses in Chafe and Tannen (1987) that lexical diversity occurs more in written discourse than spoken discourse.

In addition, the most frequent variants used were similar in several types: $\mathrm{S}$ (can/could $-\mathrm{TP}=$ 275, TPP $=90$ ). It is parallel to Seskauskiene's (2008) study which denoted that can is the most frequently used in written discourse. However, based on Riekkinen's (2009) study of spoken discourse, she found that the participants preferred using would to can/could. Importantly, both are, in the same way, included in modal verbs expressing possibility. The second one was Ap (most (ly)/(of) $\mathrm{TP}=42$, TPP $=13$ ). The third one was Ex $(($ I/researcher $)$ believe $(s)-\mathrm{TP}=1, \mathrm{TPP}=3)$. Yet, Riekkinen (2009) revealed that instead of using the word believe, the participants in her study preferred using the word think. However, the preferable variants used in Em were different: $\mathrm{TP}=(o f)$ particular (ly) (1), surprisingly (1); TPP = essentially (1).

The most frequent use of the aforementioned hedges variants in both written and spoken discourses is supposedly because those variants are the most familiar and preferable hedges variants typically taught to and digested by ELT students. This idea is supported by Seskauskiene (2008) who perceives that the high frequency of the variants denotes their somewhat easy acquisition for the students. Moreover, Web Vocabulary Profiler Classic V.4, an online computer program which divides the words into either first thousand level words, second thousand level words, academic words, or remainder / off-list words adapted by Cobb from Heatley, Nation and Coxhead (2002), indicates that the words can/could, most(ly)/(of), believe(s), (of) particular (ly) and surprisingly are classified into the first thousand level words and the word essentially is classified into the second thousand level words. This, by all means, can be the basis for the findings of this study that those hedges variants became the most frequently used variants by the students. However, this must not be the only explanation of why this phenomenon occurred. The use of those variants was definitely influenced by the content of the discourse itself. The content of the discourse affects the necessity of the use of certain variants. For instance, the students used essentially because the discourse contained the important ideas that needed to be highlighted. Also, the students used surprisingly because the discourse contained the surprising facts that had been revealed.

This finding suggests that the students need to enhance their lexical richness on hedges variants. 
Since there is a parallelism between the teaching materials used in the class and the occurrence of hedges produced by the students (Algi, 2012), it is recommended to teach hedges through an explicit instruction since it was found, based on the findings of the studies by Alward, Mooi, and Bidin (2012) and Alward (2014), to be powerful and beneficial for EFL learners. It is imperative that this important metadiscourse device be made more conspicuous to students (Hyland, 2000).

\section{CONCLUSION}

The results in this study indicate that the discourse mode (written or spoken) can be a factor that affects the use of hedges. In terms of types and frequency, the patterns of using hedges types (from the most to the least frequently used) by ELT students in both types of discourse are almost similar: WD: S-ApEm-Ex-Ch, and SD: S-Ap-Ex-Em-Ch. This pattern of the use of hedges is associated with the types which meet the writer's/speaker's intentions or purposes. Moreover, ELT students employ more hedges in written discourse than in spoken discourse. The written mode is more formal than the spoken mode; therefore, it requires the writer to produce more polite and mitigating language. Also, less direct communication and interaction between the writer and the readers make the writer take more distance from what s/he says.

In addition, ELT students use hedges variants in the taxonomy in moderate quantity in both written and spoken discourses. The number of the variants employed by the students indicates their level of lexical richness on hedges variants. Furthermore, the students employ more hedges variants in written discourse than spoken discourse, overall. It reveals that written discourse contains more lexical diversities on hedges than spoken discourse does.

On the basis of our research findings, we suggest that ELT students need to enhance their lexical richness, particularly related to hedges variants. As noted earlier, explicit instruction, in both academic writing and speaking for academic purposes, is necessary to help ELT students raise their awareness of various uses of hedges. In effect, they may use a big variety of hedges in written and spoken discourses. Finally, as far as maxim hedging is concerned, educational practitioners-English lecturers in English Departments teaching related subjects-should lead their students to move up psycholinguistically from lexical awareness to lexical use that is, from the receptive to productive skill.

\section{ACKNOWLEDGMENT}

We would like to thank the anonymous reviewer for suggesting a lot of improvements for the earlier draft of our research article. Any negligence or deficiency, however, is our responsibility alone.

\section{REFERENCES}

Agustina, R. K. (2014). Hedging expressions in the thesis discussion sections of S1, S2 and S3 students (Unpublished master's thesis). Universitas Negeri Malang, Malang.

Algi, S. (2012). Hedges and boosters in L1 and L2 argumentative paragraphs: Implications for teaching L2 academic writing (Unpublished master's thesis). Middle East Technical University, Ankara.

Alward, A. S. A. (2014). Hedges and boosters in the English as a foreign language undergraduate persuasive essays and job application letters (Unpublished doctoral dissertation). Universiti Utara Malaysia, Kedah.

Alward, A. S., Mooi, C. C., \& Bidin, S. J. B. (2012). Hedges and boosters in the Yemeni EFL undergraduates' persuasive essay: An empirical study. Language, Culture and Society, 34, 1-12.

Anthony, L. (2014). AntConc (Version 3.4.4) [Computer Software]. Tokyo, Japan: Waseda University. Available from http://www.laurenceanthony.net/.

Anthony, L. (2015). AntFileConverter (Version 1.2.0) [Computer Software]. Tokyo, Japan: Waseda University. Available from http://www.laurenceanthony.net/.

Areta, E. D. D. C. (2015). The role of discourse markers in the variational axis 'oral-written discourse' in 17th-century colonial documents. Neophilologus, 100, 43-61.

Cambridge. (2008). Cambridge Advanced Learner's Dictionary (3rd ed.) [Computer Software]. Cambridge: Cambridge University Press.

Chafe, W., \& Tannen, D. (1987). The relation between written and spoken language. Annual Review of Anthropology, 16, 383407.

Cobb, T. (2018). Web VP Classic v.4 [computer program]. Available from http://lextutor.ca/vp/eng/

Daniel, M. P., Przytula, E., \& Denis, M. (2009). Spoken versus written route directions. Cogn Process, Suppl 2(10), S201-S203.

Getkham, K. (2016). Authorial stance in Thai students' doctoral dissertation. English Language Teaching, 9(3), 80-95.

Ghasemi, H., \& Jahromi, M. K. (2014). The differences between spoken and written discourses in English. International Journal of Language Learning and Applied Linguistics World (IJLLALW), 6(4), 147-155.

Granqvist, K. P. (2013). Hedges, Boosters, and Tag Questions in The Big Bang Theory - A Gender Perspective (Unpublished BA thesis). Göteborgs Universitet, Göteborgs. 
Heng, C. S., \& Tan, H. (2010). Extracting and comparing the intricacies of metadiscourse of two written persuasive corpora. International Journal of Education and Development using Information and Communication Technology (IJEDICT), 6(3), 124-146.

Hyland, K. (1998). Boosting, hedging and the negotiation of academic knowledge. TEXT, 18(3), 349-382.

Hyland, K. (2000). Hedges, boosters and lexical invisibility: Noticing modifiers in academic texts. Language Awareness, 9(4), 179-197.

Hyland, K. (2005). Metadiscourse: Exploring Interaction in Writing. New York: Continuum.

Kaltenbock, G., Mihatsch, W., \& Schneider, S. (2010). Studies in Pragmatics 9: New Approaches to Hedging. Bradford: Emerald Group Publishing Limited.

Khajavy, G. H., Asadpour, S. F., \& Yousefi, A. (2012). A comparative analysis of interactive metadiscourse features in discussion section of research articles written in English and Persian. International Journal of Linguistics, 9(2), 147-159.

Laufer, B., \& Nation, P. (1995). Vocabulary size and use: Lexical richness in L2 written production. Applied Linguistics, 16(3), 307322.

Longman. (2006). Longman Advanced American Dictionary [Computer Software]. Edinburgh: Pearson Education limited.

Oxford. (2008). Concise Oxford English Dictionary $\left(11^{\text {th }}\right.$ ed.) [Computer Software]. Oxford: Oxford University Press.

Pedoman penulisan karya ilmiah. (2010). Malang: Universitas Negeri Malang.

Pellby, E. P. (2013). An Analysis of Hedging in an American City Council (Unpublished BA thesis). Gävle University, Gävle.

Rashady, F. A. (2012). Determining the role of hedging devices in the political discourse of two American presidentials in 2008. TESOL Journal, 7, 30-42.

Resmayani, N. P. A. (2016). The use of hedges and boosters in thesis discussion sections by Indonesian EFL learners across genders and study programs (Unpublished master's thesis). Universitas Negeri Malang, Malang

Riekkinen, N. (2009). Softening criticism: The use of lexical hedges in academic spoken interaction (Unpublished master's thesis). University of Helsinki, Helsinki.

Ruzaite, J. (2004). Academic precision reconsidered: A corpus-based account. $S K Y$ Journal of Linguistics, 17, 217-247.

Saiful. (2005). Flouting and hedging in the writings of graduate students of State University of Malang (Unpublished master's thesis). Universitas Negeri Malang, Malang.

Salager-Meyer, F. (1994). Hedges and textual communicative function in medical English written discourse. English for Specific Purposes, 13(2), 149-171.

Serholt, S. (2012). Hedges and boosters in academic writing: A study of gender differences in essays written by Swedish advanced learners of English (Unpublished paper). Göteborgs Universitet, Sweden.

Seskauskiene, I. (2008). Hedging in ESL: A case study of Lithuanian Learners. Studies about Languages, 13, 71-76.

Sundquist, C. N. (2013). The use of hedges in the speech of ESL learners. Estudios de lingüística inglesa aplicada, 13(5), 149-174.

Takimoto, M. (2015). A corpus-based analysis of hedges and boosters in English academic articles. Indonesian Journal of Applied Linguistics, 5(1), 95-105.

Wang, Y. (2010). Analyzing hedges in verbal communication: An adaptation-based approach. English Language Teaching, 3(3), 120-124. 
Appendix 1. Taxonomy of Hedges Adapted from Salager-Meyer (1994) and Hyland (2005)

\begin{tabular}{|c|c|c|c|}
\hline No. & Type & Variants & \\
\hline \multirow[t]{16}{*}{1.} & Shields & can/could & apparent (ly) \\
\hline & & may/might & argue $(\mathrm{s}) /(\mathrm{d}) /(\mathrm{ing})$ \\
\hline & & appear (s)/(ed)/(ing) & assume $(\mathrm{s}) /(\mathrm{d}) /(\mathrm{ing})$ \\
\hline & & seem $(s) /($ ed $) /($ ing $($ ly $))$ & claim (s)/(ed)/(ing) \\
\hline & & probable (ly) & unclear (ly) \\
\hline & & (un) likely & estimate $(\mathrm{s}) /(\mathrm{d}) /($ ing $)$ \\
\hline & & suggest $(\mathrm{s}) /(\mathrm{ed}) /($ ing $)$ & feel (s)/(ing)/felt \\
\hline & & speculate $(\mathrm{s}) /(\mathrm{ed}) /(\mathrm{ing})$ & guess $($ es $) /($ ed)/(ing) \\
\hline & & indicate $(\mathrm{s}) /(\mathrm{d}) /($ ing $)$ & maybe \\
\hline & & Ought & perhaps \\
\hline & & plausible (ly) & possible (ly) \\
\hline & & postulate $(\mathrm{s}) /(\mathrm{d}) /(\mathrm{ing})$ & presumable (ly) \\
\hline & & Should & suppose $(\mathrm{s}) /(\mathrm{d}) /(\mathrm{ing})$ \\
\hline & & suspect (s)/(ed)/(ing) & tend $(\mathrm{s}) /(\mathrm{ed})$ to \\
\hline & & typical (ly) & uncertain (ly) \\
\hline & & doubt (s)/(ed)/(ing)/(ful(ly)) & would \\
\hline \multirow[t]{12}{*}{2.} & Approximators of quantity, degree, & approximately & about \\
\hline & frequency and time which express heed & roughly & almost \\
\hline & and coyness & somewhat & around \\
\hline & & quite & broadly \\
\hline & & in most (cases/instances) & certain (amount/extent/level) \\
\hline & & occasionally & fairly \\
\hline & & frequent(ly) & (in) general (ly) \\
\hline & & often & (at) large (ly) \\
\hline & & mainly & $\operatorname{most}(1 \mathrm{y}) /(\mathrm{of})$ \\
\hline & & on the whole & rather \\
\hline & & relatively & usual(ly) \\
\hline & & sometimes & (in) particular (ly) \\
\hline \multirow[t]{3}{*}{3.} & Expressions which express the & (I/researcher) believe(s) & from (my/our) perspective \\
\hline & authors'/speakers' personal doubt and & to (my/our) knowledge & in (my/our) opinion \\
\hline & direct involvement & in (my/our) view & (I/researcher) think(s) \\
\hline \multirow[t]{3}{*}{4.} & Emotionally-charged intensifiers & dishearteningly & essentially \\
\hline & (comment words used to project the & (of) particular (ly) & unexpectedly \\
\hline & authors'/speakers' reactions) & surprisingly & \\
\hline \multirow[t]{3}{*}{5.} & $\begin{array}{l}\text { Compound hedges which comprise } \\
\text { "strings of hedges" (i.e. the }\end{array}$ & it would seem somewhat unlikely & it seems reasonable to assume \\
\hline & juxtaposition of several hedges) & it could be suggested that & it may suggest that \\
\hline & & it would seem likely that & \\
\hline
\end{tabular}

